\title{
Desenvolvimento Socioeconômico e Interdisciplinaridade
}

José Henrique de Faria ${ }^{1}$

\section{INTRODUÇÃO}

\subsection{Sobre a Interdisciplinaridade}

Os estudos na área do desenvolvimento social, devido ao seu caráter mesmo, são necessariamente interdisciplinares, pois recorrem à administração, à economia, à psicologia, à sociologia, à ciência política, à pedagogia, à linguística, à filosofia, ao direito, à antropologia, à engenharia, às ciências da saúde, à matemática, às ciências da saúde, entre outras disciplinas.

Portanto, torna-se necessário definir o que se entende aqui por interdisciplinaridade. Antes de iniciar a discussão, contudo, é adequado esclarecer as diferenças entre disciplinaridade, pluridisciplinaridade, multidisciplinaridade, transdisciplinaridade e interdisciplinaridade.

I. Disciplinaridade: é conjunto de conhecimentos que tem objeto próprio, aparato conceitual, sistema teórico, conceitos lógicos, linguagem própria e finalidades. Cada disciplina atua em um campo específico do conhecimento estabelecendo as fronteiras da produção do conhecimento que lhe corresponde. A disciplina possui uma abordagem circunscrita do real em torno de seu objeto científico, de maneira que sua área de ação deve ser precisamente definida. Entretanto, a atuação disciplinar não implica em um engessamento teórico, conceitual ou epistemológico. Cada disciplina possui diferentes abordagens teórico-conceituais e atua em diferentes dimensões epistemológicas.

II. Pluridisciplinaridade: consiste no estudo de um objeto por diversas disciplinas ao mesmo tempo. Cada qual com seu conjunto de saberes, em seu próprio espaço. Cada estudo tem sua própria forma, conclusão, encaminhamento. A pluridisciplinaridade se baseia na máxima “todos juntos, mas cada um por si”. O objeto é comum, mas as teorias, os métodos e

\footnotetext{
${ }^{1}$ Graduação em Ciências Econômicas pela Faculdade de Administração e Economia, Especialização em Política Científica e Tecnológica pelo IPEA/CNPq, Mestrado em Administração pela Universidade Federal do Rio Grande do Sul, Doutorado em Administração pela Universidade de São Paulo e Pós-Doutorado em Labor Relations pelo Institute of Labor and Industrial Relations da University of Michigan (2003). Professor Titular da UFPR, no Programa de Pós-Graduação em Administração (PPGADM).
} 
procedimentos, a interpretação, os focos, os limites e horizontes permanecem disciplinares. Há um compartilhamento do objeto, mas não das análises.

III. Multidisciplinaridade: consiste no estudo de objetos em que há uma troca entre disciplinas, (elas “conversam" entre si). Há uma possibilidade concreta de que se gere superposição de saberes, conflitos conceituais, divergências teóricas e diferentes abordagens metodológicas e de procedimentos de coleta e tratamento dos dados. A vantagem da multidisciplinaridade sobre a disciplinaridade e a pluridisciplinaridade é que se juntam os conhecimentos, ainda que não ocorram intercâmbios, pois ao final cada pesquisador volta à sua disciplina. Os pesquisadores compartilham do objeto, das discussões, das análises e interpretações, mas a versão que produzirão terá um caráter disciplinar ampliado, ou seja, valoriza-se a disciplina com a incorporação de elementos de outras disciplinas que sejam adequados e compatíveis com a visão disciplinar original. Em outros termos, a multidisciplinaridade é um procedimento em que as várias disciplinas concorrem para o estudo de um fato a partir de diversos olhares que se comparam, se defrontam e se complementam.

IV. Transdisciplinaridade é uma forma de pesquisa que se vale de elementos de diversas disciplinas, mas que se situa entre elas (sem pertencer a nenhuma) e que por isso pretende ir além delas. É uma metadisciplina que aspira articular níveis de realidade com o pressuposto de contemplar diferentes lógicas em uma estrutura complexa. A transdisciplinaridade tem sido relacionada à concepção pós-moderna de ciência, ou seja, à concepção que recusa os pressupostos da modernidade, enquanto herdeira do iluminismo, por considerar que esta não consegue mais dar respostas à complexidade do mundo contemporâneo. A expressão da transdisciplinaridade tem sido relacionada à Teoria da Complexidade. Transdisciplinaridade, contudo, não é o mesmo que transversalidade na pesquisa. Transversalidade é uma concepção em que os elementos disciplinares atravessam um determinado referente, cruzando-o. Por exemplo, um estudo com uma base disciplinar em geografia humana pode ser atravessado por elementos da psicologia social, que é uma disciplina que não pertence ao eixo temático da geografia humana, mas que atravessa este sistema referente na produção do conhecimento.

V. Interdisciplinaridade é a resposta à crítica que se faz ao paradigma da Ciência Moderna, especialmente naquilo que faz emergir um conflito inconciliável entre as áreas do conhecimento, separando as Ciências da Natureza das Ciências Humanas e Sociais. A interdisciplinaridade provoca um momento de forte intensidade na produção do conhecimento, pois resulta da interação entre as disciplinas. $\mathrm{O}$ conhecimento não se limita à fronteira, mas a ultrapassa. Uma reflexão interdisciplinar precisa compartilhar uma metodologia geral, uma 
linguagem teórico-metodológica, precisa articular a reflexão sobre objetos na fronteira, mas, principalmente, precisa de uma epistemologia que lhe corresponda para superar as fragilidades dos conceitos. A concepção que sustenta a noção de interdisciplinaridade é aquela que procura englobar os conhecimentos oriundos das várias áreas das ciências sociais e das humanidades e também das ciências naturais com a finalidade de estudar os fenômenos sociais em seus vários aspectos.

\subsection{Ainda a Interdisciplinaridade}

Explicitados os diferentes conceitos, pode-se afirmar que o procedimento adotado nos estudos sobre o desenvolvimento da sociedade é interdisciplinar na medida em que consiste na interação dos diversos campos do saber no estudo de um fenômeno de tal forma que as disciplinas operam conjuntamente, ao mesmo tempo, em uma direção convergente. Os resultados deste procedimento serão mais adequados quanto mais coerentes forem os quadros metodológicos e epistemológicos que agregam e integram as teorias e as disciplinas.

A interdisciplinaridade é uma prática que se desenvolve plenamente no campo empírico do processo científico, ou seja, na pesquisa e formulação da teoria. Ao contrário da ideia de que o sujeito raciocina por meio de modelos cognitivos, o pensamento é dinâmico na produção do conhecimento, compondo e recompondo as representações pela interação com a realidade, com os confrontos teóricos e filosóficos, com o desenvolvimento tecnológico e o desenvolvimento das relações sociais de produção (forças produtivas).

A interdisciplinaridade se apresenta, então, como um modo de organização e articulação de saberes disciplinares na prática da pesquisa, nutrindo-se delas sem dissolvê-las, especialmente quando a solução de um problema de pesquisa é invisível no âmbito de uma única disciplina. Isto porque o real concreto é o resultado de diversas interações entre fenômenos, é uma "síntese de múltiplas determinações" (MARX, 1974). Desta forma, como as disciplinas em geral se dedicam a fenômenos e objetos que lhes são próprios, para a compreensão destas múltiplas determinações, das diversas, dinâmicas e contraditórias interações entre os fenômenos, é necessário romper as fronteiras disciplinares. A condição de "circular livremente" entre as fronteiras estabelecidas nas e pelas disciplinas é uma prática interdisciplinar.

A interdisciplinaridade, por conseguinte, não é simplesmente uma escolha diante da limitação das disciplinas, não é uma simples opção de obter uma vitória sobre as deficiências disciplinares, mas o desenvolvimento da capacidade de superar as disciplinas sem aboli-las. É, 
consequentemente, uma articulação compartilhada de abordagens próprias das disciplinas, pois sem estas a própria interdisciplinaridade seria impossível. Como bem observa Claude Raynaut, a formação interdisciplinar sem a formação disciplinar faz surgir um "Frankestein do Conhecimento", um ser bem costurado, mas que não sabe andar corretamente. Com este sentido é que se pode afirmar que a interdisciplinaridade não tem origem na definição que dela se faz a partir de uma abstração arbitrária, mas do que se pode construir a partir de sua prática.

A interdisciplinaridade aliada a uma epistemologia crítica é marcada pela primazia do objeto e não da teoria, pelo primado da realidade e não da ideia e é neste sentido que também difere da transdisciplinaridade ou das concepções denominadas de holísticas e pós-modernas. Especialmente porque estas pretendem ser a superação do conhecimento produzido através das disciplinas, opondo-lhe uma forma metadisciplinar e um saber transcendental. Tal projeto é, para epistemologia crítica, de natureza metafísica, ou seja, um projeto da ideia e, portanto, inconsistente com os propósitos dessa epistemologia.

A interdisciplinaridade decorre da necessidade de se dar conta de novos problemas, de diferentes naturezas e com níveis de complexidade crescentes, muitas vezes decorrentes do próprio avanço dos conhecimentos científicos, filosóficos e tecnológicos. A natureza complexa, dinâmica e contraditória destes problemas exige não só diálogos entre disciplinas próximas, dentro da mesma área do conhecimento. Exige, também, diálogos entre disciplinas de áreas diferentes, como uma interação entre os saberes disciplinares e entre estes e os não disciplinares oriundos da sociedade, das relações de produção das condições materiais de existência e das culturas.

Daí a relevância de novas formas de produção de conhecimento que tomam o objeto como um fenômeno que se coloca entre ou além das fronteiras disciplinares. Não se trata simplesmente de optar pela interdisciplinaridade como recurso alternativo diante da incapacidade das disciplinas fazerem uma leitura mais profunda da realidade. Isto pode até mesmo acontecer, porém a interdisciplinaridade deve ser uma prática que independe das condições, do alcance e dos limites das disciplinas. A interdisciplinaridade é um modo de produção do conhecimento que supera os desafios teóricos e metodológicos dos diferentes campos da ciência, da filosofia e da tecnologia.

A sociedade historicamente sempre se relacionou de forma interdependente com os conhecimentos, com as relações sociais de produção das condições materiais de existência e com a cultura. A complexidade dinâmica e dialética não está na constatação do que sempre existiu na constituição da sociedade em seus diferentes modos de produção, mas no 
desvendamento das inúmeras e cada vez mais amplas relações entre os fenômenos condicionadas pelo desenvolvimento das forças produtivas. Portanto, não existem objetos permeáveis e refratários a uma leitura interdisciplinar, mas uma escolha do pesquisador a qual decorre de sua preferência, da limitação concreta do acesso ao objeto, da ênfase, enfim, de um corte sempre necessariamente arbitrário no modo de conhecer cientificamente a realidade. Destarte, o pesquisador deve considerar suas práticas tanto quanto os processos de produção e transmissão do conhecimento, processos estes nos quais se recolocam tanto as transformações estudadas como aquelas que as mesmas provocam com o desenvolvimento deste conhecimento.

Quanto mais se desenvolvem e se aprofundam as pesquisas, as tecnologias e o saber filosófico, mais se colocam, aos pesquisadores, novos e diferentes problemas. A ideia de que os problemas e as incertezas atuais são tantas que se justifica uma teoria da complexidade para desvendá-los, não é mais do que a absolutização da relativização. Historicamente, pode-se constatar que ao mesmo tempo em que os problemas e as incertezas se expandem, também se expandem as tecnologias, as teorias, os instrumentos de pesquisa, os sistemas e redes de comunicação em tempo real, a circulação e o acesso às informações, enfim, os desafios à produção do conhecimento. Em outras palavras, os problemas e as incertezas se expandem quanto mais eles são conhecidos em sua essência e em suas relações e quanto mais se expandem as condições concretas de produção do conhecimento. Como sugere Marx (1977 - Prefácio) “a humanidade só se coloca problemas que ela pode resolver, pois [...] o problema só é proposto onde as condições materiais necessárias à sua solução já existem, ou, pelo menos, estão em vias de aparecimento".

Os pensamentos disciplinares, multidisciplinares, interdisciplinares e transdisciplinares, constituem-se em formas diferenciadas e às vezes complementares de geração de conhecimentos. Assim, o desafio epistemológico é o de identificar características e âmbito de atuação de cada uma dessas modalidades de geração de conhecimento nas diferentes áreas, assim como as suas trajetórias, possibilidades, horizontes e limites. A interdisciplinaridade precisa reconhecer que diferentes concepções podem ser adotadas nas pesquisas e na pedagogia, pois é possível construir significados distintos, valorizando e reconhecendo a diversidade que a produção do conhecimento requer.

Fazer este percurso de forma interdisciplinar é entender que quem comanda o processo de produção do conhecimento é o pensamento que se apropria da realidade como realidade pensada e não as disciplinas. As disciplinas explicam apenas o seu objeto e de um ponto de 
vista circunscrito. A interdisciplinaridade, ao romper com a tradição disciplinar, exige uma epistemologia crítica, e não um paradigma tradicional.

Assim, é a partir do objeto do conhecimento que se constrói o conhecimento. O objeto não possui uma disciplina, ainda que esta possua um objeto. Desta maneira, o olhar dirigido ao objeto é sempre e necessariamente condicionado por este e por suas inúmeras relações, sua complexidade e suas contradições. Por exemplo: ao estudar um movimento social que luta pelo desenvolvimento sustentável de seu território, é necessário considerar a perspectiva da política (pública), da sociologia, da economia, da gestão, da psicologia social, da história, da antropologia, do discurso (linguagem), da educação ambiental, da engenharia ambiental, das áreas da saúde (medicina, odontologia, nutrição, etc.), entre outras. Todos estes fatores encontram-se ao mesmo tempo no mesmo objeto de estudo. O olhar disciplinar separa cada parte do problema conforme a disciplina. O multidisciplinar e o pluridisciplinar colocam cada parte do problema lado a lado para, a partir de uma discussão, poder agrupar as diversas concepções. O interdisciplinar considera que a compreensão do objeto demanda os olhares de todas as disciplinas ao mesmo tempo, pois entende que todas se relacionam, ou seja, que são aspectos de um mesmo fenômeno. A interdisciplinaridade deve considerar o primado do real sobre as disciplinas, ou seja, é a realidade que exige uma abordagem interdisciplinar e que define, por sua forma e conteúdo, os olhares integrados necessários para desvendar seus elementos constitutivos.

A interdisciplinaridade, portanto, procura produzir, como síntese de suas práticas, um conhecimento comum a todas as disciplinas, porém que ultrapasse as contribuições de cada uma delas. Assim, cabe recolocar a concepção de que a interdisciplinaridade não é dada de uma vez pela simples aproximação entre as disciplinas, com suas origens e horizontes, mas como uma construção por meio de um processo metódico, pois a produção do conhecimento no campo interdisciplinar exige uma inovação contínua no domínio das relações com o real concreto, com o objeto, com a matéria do conhecimento.

\section{O DESENVOLVIMENTO SOCIOECONÔMICO E A BI-DISCIPLINARIDADE}

A concepção de um desenvolvimento socioeconômico é, em si mesma, restrita a duas disciplinas: sociologia e economia. No entanto, o desenvolvimento da sociedade requer mais do que duas disciplinas, por mais que e expressão "sócio" pretenda dizer além do que realmente diz. De fato, o senso comum atribui à expressão "sócio" uma extensão que a mesma não possui. 
Problemas relativos, por exemplo, à saúde, transporte, educação, segurança, aparatos jurídicos, ideologia, cultura, relações de trabalho, planejamento urbano, são enquadrados como se fossem simplesmente sociais. Trata-se de uma redução disciplinar. O desafio está justamente em fazer do conjunto das disciplinas uma interdisciplina.

\subsection{Da Economia ao par Economia-Sociologia}

De início, o problema do desenvolvimento era estritamente econômico. Esta concepção ainda prevalece no âmbito da economia. A concepção original era a de que o desenvolvimento econômico produziria, por si mesmo, um desenvolvimento social. Assim, as políticas desenvolvimentistas tratavam do incremento da capacidade produtiva medida por variáveis tais como poupança, relações comerciais, níveis de consumo, distribuição de renda, entre outros indicadores, acreditando que estes indicariam melhorias na qualidade de vida, educação, saúde, analfabetismo e infraestrutura urbana e social.

Entre os indicadores mais conhecidos estão os que tratam da distribuição de renda:

a) O Coeficiente de Gini é uma medida utilizada para calcular a desigualdade de distribuição de renda, mas pode ser usada para qualquer distribuição. Ele consiste em um número entre 0 e 1 , onde 0 corresponde à completa igualdade de renda ou rendimento (onde todos têm a mesma renda) e 1 corresponde à completa desigualdade (onde uma pessoa tem toda a renda ou rendimento e as demais nada têm). $\mathrm{O}$ índice de Gini é o coeficiente expresso em pontos percentuais (é igual ao coeficiente multiplicado por 100). O coeficiente de Gini é usado para medir a desigualdade de renda ou rendimento, porém pode ser também usado para mensurar a desigualdade de riqueza. Esse uso requer que ninguém tenha uma riqueza líquida negativa

b) O Índice de Theil é uma medida estatística da distribuição de renda na qual se usa o logaritmo neperiano da razão entre as médias aritméticas e geométricas da renda familiar per capita média. Se a razão entre as médias for igual a 1, Theil será igual a zero, indicando perfeita distribuição. Quanto maior a razão entre as médias, maior será o valor para o índice de Theil, e pior será a distribuição de renda. Este valor está entre 0 e 1 e quanto maior este valor, pior a distribuição. O Índice de Theil, calculado por Theil em 1967, é baseado no conceito de entropia de uma distribuição. Entre suas qualidades enumeram-se que é simétrico (tem a propriedade de invariância em caso de permuta de indivíduos), é invariante à replicação (é independente de replicações de população), independente da média (tem a propriedade de ser invariante em caso de alteração da escala da renda), e satisfaz o Princípio de Pigou-Dalton (a desigualdade cresce como resultado de transferências regressivas.

Posteriormente, foram incluídas, nos indicadores, questões chamadas de sociais, tais como nível de educação, infraestrutura urbana, saúde. Entre estes indicadores, destacam-se:

c) $\mathrm{O}$ Índice de Pobreza Humana (IPH) serve como indicador da taxa de pobreza que existe em determinado país. Este indicador faz a ponderação de três variáveis: (i) Curta duração da vida (o percentual da população, em cada país, que não atinge os 40 anos); (ii) Falta de educação elementar (o percentual da população analfabeta); (iii) Falta de acesso aos recursos públicos e privados (percentagem composta das pessoas com falta de acesso ao serviço de saúde, água potável e nutrição razoável). O IPH considera diversos indicadores para verificar a porcentagem de pessoas em uma população que sofre de privações em quatro dimensões básicas da vida: a longevidade, o conhecimento, a provisão econômica e a inclusão social;

d) Um dos mais considerados indicadores é o IDH. Os Relatórios do Programa das Nações Unidas para o Desenvolvimento - PNUD apontam alguns fatores que compõem o Índice de Desenvolvimento 
Humano - IDH. O IDH é calculado a partir de indicadores de educação (alfabetização e taxa de matrícula), saúde (esperança de vida) e renda (PIB per capita) e avalia as condições comparadas de desenvolvimento humano no mundo, identificando os países de alto, médio e baixo desenvolvimento. $\mathrm{O}$ PNUD mostra o que a ONU chama de desigualdades mundiais grotescas e indica que o processo recente de globalização está contribuindo para acentuar as desigualdades sociais entre os países. No entanto, este indicador não mostra, por exemplo, que a concentração de riqueza pessoal é extraordinária: os ativos dos dez maiores multimilionários do mundo em 2012, segundo a Revista Forbes, somam o equivalente a US\$ 395,5 bilhões, o que é superior à somatória do PIB dos 10 países mais pobres do mundo (US\$ 376,9 bilhões).

Com isso, a literatura tratou de diferenciar crescimento de desenvolvimento econômico. $\mathrm{O}$ crescimento econômico trataria somente das questões propriamente econômicas, tais como Produto e Renda (PIB, PNB, etc.), Gastos do Governo, Consumo das Famílias, Poupança/Investimento, exportação e Importação, na clássica fórmula keynesiana ( $\mathrm{Y}=\mathrm{C}+\mathrm{I}+$ $\mathrm{G}+\mathrm{X}-\mathrm{M}$, em que $\mathrm{C}=\mathrm{Co}+\mathrm{bY})$. $\mathrm{O}$ desenvolvimento econômico trataria também de questões sociais, tais como bem-estar, nível de consumo, IDH, taxa de desemprego, analfabetismo, qualidade de vida, entre outros. Com o tempo, a literatura inclui uma nova expressão: desenvolvimento socioeconômico, para qualificar a ideia de desenvolvimento econômico. Contudo, esta nova expressão não alterou as formas de medida utilizadas. No campo crítico da economia, o conceito de desenvolvimento aparece acompanhado do termo "capitalista", para diferenciar o desenvolvimento social daquele especificamente capitalista.

\subsection{A Ausência de uma Política de Desenvolvimento de Caráter Interdisciplinar}

O uso do conceito de desenvolvimento socioeconômico e seu atrelamento aos indicadores mostra claramente que não há uma concepção interdisciplinar. Com alguma boa vontade, pode-se mesmo admitir que se trata de uma visão multidisciplinar restrita. Os indicadores de educação e saúde, por exemplo, pouco revelam sobre a real situação da saúde da população e sobre o processo de educação. Isto sem mencionar problemas atuais como transporte, segurança, planejamento urbano, mobilidade social, violência e o conjunto da infraestrutura urbana e social.

A questão que se deve propor é: como adotar uma concepção interdisciplinar no que se refere ao desenvolvimento socioeconômico? Como considerar que um projeto de desenvolvimento trate, simultaneamente, da educação, do direito, da economia, das engenharias, do campo da saúde física e mental, da agricultura, da preservação sustentável do ambiente, das questões sociais, das tecnologias (da biotecnologia), do processo político, da cultura e da arte, do emprego e do processo de trabalho, do desenvolvimento científico, enfim, de todas as disciplinas que concorrem para que o desenvolvimento se faça em sua totalidade? 
Como considerar o desenvolvimento como um processo democrático e justo de vida coletiva que tem, nos indicadores, apenas o que eles são, ou seja, simples indicadores e não determinantes?

Talvez seja preciso ousar uma proposta que possa dar conta desse problema: o desenvolvimento socioeconômico democrático de caráter interdisciplinar deve ser considerado a partir de critérios de justiça social.

\section{CRITÉRIOS DE JUSTIÇA PARA O DESENVOLVIMENTO SOCIOECONÔMICO INTERDISCIPLINAR: por uma democracia social.}

A categoria analítica hegeliana da luta pelo reconhecimento foi retomada recentemente pela terceira geração da Teoria Crítica frankfurtiana através do filósofo e sociólogo Axel Honneth (2009), que postula uma investigação empírica no campo da sociologia do reconhecimento, do filósofo político canadense Charles Taylor (2000; 2005), que busca na filosofia histórica as bases do reconhecimento social como o vínculo fundamental entre os sujeitos, e de Nancy Fraser (2003), cientista política norte-americana que se dedica aos estudos dos movimentos sociais e dos conflitos políticos. Honneth (2009, p. 274) conclui que existem três formas de reconhecimento: do amor, do direito e da solidariedade. Estas formas estruturam "dispositivos de proteção intersubjetivos que asseguram as condições de liberdade externa e interna, das quais depende o processo de uma articulação e de uma realização espontânea de metas individuais de vida". Entretanto, apenas dois, dos três padrões de reconhecimento encerram o potencial de um desenvolvimento normativo mais amplo. Apenas "a relação jurídica [e] a comunidade de valores estão abertas a processos de transformação no rumo de um crescimento de universalidade ou igualdade". Para Honneth, portanto, a redistribuição é derivada do reconhecimento.

Todavia, em uma crítica correta e pertinente feita a Axel Honneth e à sua concepção de reconhecimento como categoria moral, em um debate de grande profundidade, Nancy Fraser (FRASER; HONNETH, 2003) apresenta uma proposta dualista, na qual reconhecimento e redistribuição são duas categorias irredutíveis entre si. Esta concepção de Fraser recebeu uma crítica de Iris Young (1990), que a considerou distributivista. Entretanto, posteriormente, a estas duas categorias analíticas Fraser (2008a; 2008b) adiciona a da luta pela representação política (FRASER, 2008a; 2008b), em uma perspectiva tridimensional. Fraser insiste em que os conflitos sociais não podem ser explicados apenas a partir da luta pelo reconhecimento social, mas igualmente através da luta pela redistribuição da riqueza material produzida pela sociedade 
e pela representação paritária nas esferas de decisão. Estas três formas, para Fraser, correspondem a três dimensões da justiça: cultural (reconhecimento); econômica (redistribuição); política (representação). Assim, do ponto de vista analítico, emergem três categorias: reconhecimento social; redistribuição igualitária da riqueza material; representação paritária nas esferas de decisão.

Contudo, é necessário argumentar para além do que a teoria crítica contemporânea o faz, pois esta, ao contentar-se em centrar a análise da realidade a partir destas três categorias, acaba tratando o sujeito da ação de forma parcial, pela abstração do sujeito real e pelo falseamento de sua constituição prática. De fato, ao recusar o reconhecimento do amor, Honneth retira o mesmo do processo de transformação como se a questão emocional pertencesse apenas à esfera individual. Fraser, igualmente, não inclui nas três dimensões uma que signifique a categoria da recompensa psicológica na vida afetiva dos grupos (PAGÈS, 1982). De fato, há nestas análises a ausência do sujeito coletivo concreto, daquele que é ao mesmo tempo sujeito do reconhecimento (sujeito reconhecido ao outro, pelo outro e para o outro), quanto o sujeito que se reconhece (sujeito coletivo reconhecido por si, do ponto de vista ontológico, e para si, como um ser consciente). Em outras palavras, a materialização do sujeito coletivo reclama que este se apresente tanto na luta para ter seu desejo reconhecido ao, pelo e para o Outro, quanto para que se reconheça por e para si como portador do desejo, ou seja, é preciso contemplar o ser da razão e da emoção ao mesmo tempo. Neste sentido, é necessário admitir a ausência, nestas teorias, de uma categoria analítica que possa dar conta desta dimensão constitutiva do sujeito coletivo concreto em sua prática racional e emocional. Esta carência pode ser atendida através da categoria analítica da realização ou recompensa emocional, na medida em que esta represente a materialização do sujeito coletivo como componente da prática da luta pelo reconhecimento, pela redistribuição e pela representação. A análise deve ser, por conseguinte, quadridimensional e não tridimensional como propõe Fraser (2008a) e guiada por quatro categorias de análise:

$i$. Redistribuição igualitária da riqueza material coletivamente produzida, a qual corresponde à dimensão econômica;

ii. Reconhecimento social, à qual corresponde a dimensão cultural;

iii. Representação paritária nas esferas de decisão, à qual corresponde a dimensão jurídica-política;

iv. Realização emocional, à qual corresponde a dimensão psicossocial.

A partir daí, a questão que se coloca é: por que estas categorias analíticas podem ser úteis para se pensar interdisciplinarmente o desenvolvimento socioeconômico em uma perspectiva democrática social? São úteis por dois motivos: Primeiro, porque estas categorias delimitam o campo empírico da ação ao materializar (i) o sujeito coletivo no plano do grupo social (reconhecimento e realização) bem como (ii) as formas de organização e de gestão da 
prática política (redistribuição e representação). Segundo, porque também delimitam o plano epistemológico, metodológico e teórico daí decorrente.

$\mathrm{O}$ argumento que se desenvolve aqui recorre àquele proposto por Fraser $(2003 ; 2008 \mathrm{a})$, segundo o qual os sujeitos coletivos:

- Lutam pelo reconhecimento social como forma de integração plena na sociedade como sujeitos iguais;

- Lutam por uma redistribuição isonômica, igualitária e justa da riqueza material enquanto resultado da produção de suas condições de existência; e

- Lutam pela representação política nas esferas de decisão como forma de pertença social e como procedimentos que estruturam os processos públicos de confrontação.

A estas categorias acrescenta-se outra. Os sujeitos coletivos lutam também pela sua realização no plano emocional na medida em que é da condição humana a demanda psicológica por recompensa decorrente do empenho de energia política no processo de luta social. A concepção que se defende aqui se vincula a uma teoria que busca encontrar inspiração nas avaliações críticas da realidade afastando-se tanto das interpretações que fazem da ideologia a própria teoria, quanto das que não consideram que os estudos que tratam dos aspectos objetivos e subjetivos do desenvolvimento subsistem na análise de um mesmo fenômeno.

\subsection{As categorias analíticas e sua fundamentação epistemológica e metodológica}

Como indicado anteriormente, a proposta que se faz aqui é a de estudar o processo de desenvolvimento socioeconômico a partir de quatro categorias de análise à qual correspondem quatro dimensões. Por que se utilizar destas categorias na contemporaneidade? Em primeiro lugar, devido à falência dos modelos e das crenças em modelos alternativos para o sistema de capital no atual ordenamento jurídico-político, ideológico e econômico (FRASER, 1997, p. 13). A deslegitimação e o colapso do chamado socialismo real e dos arranjos institucionais que pudessem viabilizar formas não capitalistas de produção transformaram substancialmente os meios de enfrentamento, abrindo espaço para a assimilação das lutas sociais pelo sistema de capital.

Em segundo lugar porque existe um hiato na gramática das demandas sociais por reconhecimento, demandas econômicas por redistribuição, demandas políticas por representação e demandas psicossociais por realização no plano do desenvolvimento. Hiato este que precisa ser preenchido, pois as demandas expressas por diferentes grupos sociais visando à igualdade dos direitos e condições de vida em sociedade apontam para o declínio da identidade política de classe (declínio da democracia) e do imaginário político por justiça social. Assim, no lugar da luta de classes aparecem os grupos sociais delas desvinculados que lutam por seus 
interesses jurídico-políticos, econômicos e ideológicos, tanto quanto pela dominação cultural. Desta forma, no lugar da ampla luta social pelo desenvolvimento socioeconômico se organizam as lutas simplificadas pela melhor distribuição da riqueza; no lugar da luta pela igualdade, a isonomia e a emancipação social se organizam as lutas simplificadas pelo reconhecimento; no lugar da plena, paritária e democrática participação do conjunto da sociedade na definição do seu projeto coletivo de desenvolvimento, se organizam as lutas simplificadas pelo direito à representação política; no lugar da realização dos sujeitos coletivos enquanto sujeitos da ação, da razão e da emoção, se organizam as lutas simplificadas pela recompensa psicológica através de artifícios manipulativos.

Em terceiro lugar porque enquanto uns defendem o reconhecimento social como se a luta pela justiça redistributiva, pela representação paritária e pela realização emocional não fossem relevantes, outros, baseados no declínio do igualitarismo econômico desejam recolocar tão somente as classes sociais no centro da vida em sociedade (FRASER, 1997). Tudo ocorreria como se a luta contra o racismo, o preconceito e a discriminação de gênero e opção sexual, por exemplo, fossem apenas meramente culturais e não tivessem qualquer relação com a redistribuição da riqueza material, o reconhecimento social, a representação paritária e a realização emocional. Estes constructos colocam em lados opostos: $i$ ) política de classe e identidade política; $i$ ) política social e política cultural; iii) redistribuição e reconhecimento.

Estas três razões que levam à adoção das categorias analíticas não pretendem esgotar os argumentos em defesa das mesmas. Assim, tais dimensões são expostas a seguir com o objetivo de explicitar no plano conceitual o que se encontra no plano empírico das categorias. Antes, contudo, de prosseguir na exposição é fundamental esclarecer cinco pontos desta discussão que dizem respeito exatamente aos condicionantes epistemológicos, metodológicos e teóricos das categorias.

O primeiro, como não poderia deixar de ser, refere-se ao método. As distinções analíticas que se seguem, mais precisamente entre reconhecimento social, redistribuição material, representação política e realização emocional, encontram-se no plano do real concreto estritamente ligadas, imbricadas, sem distinção prática. Contudo, como indica Fraser (2008b, p. 13), "para propósitos heurísticos, distinções analíticas são indispensáveis. Apenas abstraindo a complexidade do mundo real pode-se divisar um esquema conceptual que possa iluminá-lo". Ainda para Fraser (2008b, p. 16), a "distinção entre injustiça econômica e injustiça cultural é analítica. Na prática, ambas estão entrelaçadas. Mesmo a mais material instituição econômica tem uma dimensão cultural constitutiva, irredutível (...). Reciprocamente, mesmo a mais 
discursiva prática cultural tem uma dimensão político-econômica constitutiva, irredutível”. Longe de serem duas esferas hermeticamente separadas, estas dimensões estão imbricadas, de modo que se reforçam dialeticamente.

O segundo refere-se ao fato de que a condição para que um grupo social seja reconhecido no processo de desenvolvimento socioeconômico não implica necessariamente sua adesão ao modelo econômico, jurídico-político, social, cultural ou psicossocial que o reconhece, ou seja, a luta pelo reconhecimento não se trava nos termos dos grupos sociais ou da classe social dominante. O reconhecimento não implica que o grupo social seja reconhecido como uma parte, mesmo que excluída, daquele que reconhece (como Si Mesmo), mas que seja reconhecido como seu contrário com direito à plena existência (como o Outro).

O terceiro refere-se ao fato de que a redistribuição da riqueza material socialmente produzida não significa necessariamente uma inserção do grupo social ao sistema de capital como parte inerente do mesmo, ainda que com uma condição periférica. Também não significa que a distribuição ocorra apenas nas atividades produtivas não capitalistas. Trata-se de distribuir o conjunto da riqueza material produzida tanto nas atividades de produção não capitalistas como aquelas produzidas pelo sistema de capital, mas não nos termos deste. $\mathrm{O}$ fato de que sob o sistema de capital a riqueza material seja produzida pelo trabalhador, que dela não se apropria (alienação), não deve implicar em sua não redistribuição sob o argumento da manutenção ou reprodução de tal sistema. Ao contrário, não se trata de uma conciliação entre capital e trabalho, mas no estabelecimento de um modo de redistribuição da riqueza material socialmente produzida na direção oposta à acumulação do capital. Aqui também é necessariamente imperativo desmitificar a ideologia capitalista do desenvolvimento baseada nas concepções de liberdade, democracia liberal e direitos iguais como promotores da distribuição da renda, do reconhecimento social, da representação parlamentar e da satisfação pessoal pela obtenção de resultados, na medida em que tais concepções estão restritas aos interesses do sistema de capital.

O quarto refere-se ao fato de que a participação paritária dos grupos sociais nos processos de decisão que lhes dizem respeito não significa necessariamente a adoção, por estes, das regras impostas pelos grupos sociais ou pela classe social dominante. Não se trata, aqui, somente de questionar a efetividade da democracia burguesa no asseguramento da justiça social ou nos impedimentos da apropriação privada dos recursos públicos: desde seu início a democracia representativa burguesa se caracterizou exatamente pelas formas mais explícitas ou sofisticadas, segundo o ordenamento legal ou não, de distribuição de privilégios. Trata-se de 
assegurar o direito à participação paritária nas decisões que dizem respeito ao desenvolvimento socioeconômico em todas as esferas da vida social nos termos definidos direta e democraticamente pelo coletivo.

O quinto, finalmente, refere-se ao fato de que a realização ou a recompensa emocional não significa necessariamente a adoção de modelos de normalidade psicológica que são estabelecidos de acordo com a lógica do sistema de capital. Não se trata aqui somente de questionar a psiquiatria que se desenvolve sob o sistema de capital, com seus processos de tratamentos hospitalares ou com os impedimentos ao acesso coletivo aos avanços da ciência, inclusive, ou especialmente, no que se refere às impossibilidades concretas de acesso aos medicamentos produzidos pela indústria farmacêutica. Trata-se, também, da necessidade do reconhecimento no campo emocional, o que significa que a realização ou recompensa está vinculada à condição de reconhecimento do outro e à de ser reconhecido ao outro e pelo outro (ZIMERMAN, 1999, p. 163).

A explicitação destes cinco pontos preliminares tem a finalidade de indicar a direção epistemológica, metodológica e teórica que guia esta proposta de construção de um processo democrático de desenvolvimento socioeconômico, a qual se concentra na dialética da pertença. Neste sentido, a leitura do real concreto se estabelece segundo uma unidade de contrários no que se refere às relações dos grupos sociais no sistema de capital, tanto como elementos incluídos neste, quanto como elementos que constituem a resistência a este em seus vários aspectos. Trata-se, em seguida, de examinar cada uma das categorias, submetendo-as, até onde é possível, a um escrutínio crítico, identificando a dimensão emancipatória das mesmas em termos do desenvolvimento socioeconômico e integrando-as em um modelo simples de análise do real concreto.

\subsection{A redistribuição igualitária da riqueza material coletivamente produzida: a dimensão econômica da análise}

O ponto de partida para o aprofundamento da reflexão sobre a dimensão econômica é reconhecer a relação que se estabelece entre as organizações ou unidades produtivas e o modo de produção. Seja qual for a natureza social específica da organização, deve-se reconhecer que a mesma se constitui no interior de um determinado modo de produção - e não a par dele - seja com a finalidade de reprodução deste sistema seja como mecanismo de resistência a ele. Neste sentido, a análise deve partir da compreensão dos elementos fundamentais do modo de 
produção capitalista, para estabelecer categorias gerais sobre o nível econômico do controle social.

Tendo em vista a tendência do sistema de capital à concentração da riqueza e dada sua lógica de exploração daqueles que diretamente a produzem, a análise da distribuição igualitária da riqueza material coletivamente produzida não deve simplesmente tratar da repartição da renda e tampouco ocupar-se da valorização da utopia (neo)liberal de que é possível estabelecer uma partilha justa da riqueza sob este modo de produção. Esta categoria deve considerar não apenas as formas como a renda social são redistribuídas, mas igualmente as formas de propriedade, as relações de troca das mercadorias (produtos e serviços), a organização, os processos e as relações de trabalho e o acesso aos bens de infraestrutura social urbana e rural (educação, saúde, saneamento, segurança, moradia, entre outros). A análise desta categoria não deve pressupor, igualmente, um pleito utópico a favor de um modo pós-capitalista de produção, ou seja, de um socialismo democrático ou uma autogestão social, ainda que esta seja a condição histórica de tal projeto. Trata-se de analisar, aqui, a ocorrência ou não de uma justiça distributiva tanto nas condições de reprodução e de acumulação capitalista como nas das forças coletivas organizadas de resistência ou de enfrentamento dos processos de exclusão social pelo sistema de capital. As possibilidades concretas, neste sentido, encontram-se no desenvolvimento, mesmo que primário, das formas de transição.

Por conseguinte, não se pretende aqui estabelecer um quadro teórico apriorístico que tenha por consequência a constatação de características capitalistas ou anticapitalistas em quaisquer processos de desenvolvimento socioeconômico que venham ser analisados.

A categoria da redistribuição envolve, de acordo com Fraser (2008b, p. 17), a redistribuição dos rendimentos, a reorganização da divisão do trabalho, subordinação dos investimentos a um processo democrático de tomada de decisão e transformação das estruturas básicas da economia. Tais questões, naturalmente, não se referem à construção de um imaginário socialista, mas a um projeto de transformação que permita acentuar as contradições do sistema de capital. Isso poderia envolver a revalorização ascendente de identidades desrespeitadas e os produtos culturais de grupos excluidos. Também poderia envolver reconhecimento e valorização positiva da diversidade cultural. Mais radicalmente ainda, poderia envolver a total comunicação, de forma que se alteraria a percepção coletiva que todos têm de si mesmos. Assim, toda medida que repara uma perda redistributiva ou que restabelece uma relação econômica pressupõe uma concepção subjacente de reconhecimento social. É neste sentido que as reivindicações pela redistribuição muitas vezes reclamam a abolição de arranjos 
econômicos que sustentam a especificidade de determinados grupos sociais, como é o caso, por exemplo, da demanda, por grupos feministas, pela abolição da "divisão sexual" do trabalho ou da organização do trabalho baseada em gênero.

De fato, ainda de acordo com Nancy Fraser (2008b, p. 23), o gênero possui uma dimensão político-econômica, constituindo-se em um princípio estruturador básico da política econômica. De um lado, o gênero estrutura a divisão fundamental entre o pagamento de trabalho "produtivo" e o não pagamento de trabalho "reprodutivo" e doméstico, atribuindo às mulheres uma responsabilidade primária por este último. De outro lado, o gênero também estrutura a divisão do trabalho pago entre a alta remuneração, dominada pelos homens nas unidades produtivas e nas ocupações profissionais, e a baixa remuneração, dominada pelas mulheres ("Pink-Collar") nas ocupações de serviços domésticos. O resultado é uma estrutura político-econômica que gera modos específicos de exploração, marginalização e privação baseados em gênero.

O mesmo dilema, de acordo com Fraser (2008b, p. 25-26) pode ser encontrado na luta contra o racismo, a qual se assemelha à questão do gênero na estrutura político-econômica. A "raça" também estrutura a divisão capitalista do trabalho revelando a baixa remuneração, o baixo status, a atividade subalterna, o trabalho sujo e as ocupações domésticas executadas desproporcionalmente por afrodescendentes, e a alta remuneração, o alto status, o "WhiteCollar" e as ocupações profissionais, técnicas e de gestão, exercidas desproporcionalmente por brancos. A "raça" estrutura o acesso ao mercado de trabalho constituindo uma parcela significativa de negros e pardos como supérfluos, lumpemproletários, subclasses, indignos, inclusive pela não inserção dos mesmos no sistema de capital.

\section{RECONHECIMENTO SOCIAL: DIMENSÃO SOCIOCULTURAL DA ANÁLISE}

O tema do reconhecimento social é resgatado na discussão contemporânea devido à emergência dos movimentos sociais que ultrapassam a tradicional divisão de classes contemplando questões como gênero, preconceito, desemprego, direitos sociais urbanos, educação, saúde pública, segurança, moradia, infraestrutura urbana e rural, sustentabilidade ambiental, entre muitos outros. A centralidade das lutas sociais desloca-se do conflito de classes conduzido historicamente pelos movimentos de trabalhadores estabelecendo uma nova agenda de enfrentamentos. Isto não implica o desaparecimento das classes sociais e dos conflitos fundamentais que possuem existência real no modo de produção capitalista, mas indica que as 
lutas alcançam outras dimensões que necessitam ser compreendidas em uma perspectiva crítica. Isto não significa propor um esquema normativo, programático e totalizador abrigado nas denominações de "desconstrução", "reformismo", "pós-modernismo" ou "teoria da complexidade". Como sugere Fraser (1997, p. 4), não se trata, igualmente, da proposição de um novo projeto para o socialismo, mas de conceber alternativas para o atual estágio da sociedade que possam oferecer uma base de discussão para uma política progressiva de superação do sistema de capital.

Não se pode deixar de observar que as mudanças estruturais e normativas somente podem ocorrer pela ação coletivamente organizada dos membros dos grupos ou das classes sociais. Assim, é apenas com o assentimento do coletivo, solidamente suposto, que o sujeito coletivo pode estabelecer uma relação de pertença que viabilize e legitime as transformações. Os sujeitos coletivos que lutam por mudanças nas regras precisam, antes, reconhecê-las como tais, bem como suas motivações, os interesses que expressam, os acordos e as articulações que as viabilizaram. Se a ação transformadora se efetiva é porque os sujeitos não se submetem, ainda que reconheçam as regras. A questão que está mal resolvida na abordagem que coloca o conflito social como objeto de uma teoria crítica da sociedade e a luta pelo reconhecimento como sua gramática, é exatamente a diferença fundamental entre ser reconhecido pela conformação às regras e às normas definidas pela sociedade na interpretação dos interesses dominantes e ser reconhecido por admitir a existência das regras, mas lutar contra as mesmas para transformá-las. Análises como, por exemplo, a de Honneth (2009), não obstante se empenhem na análise da emancipação da dominação apresentando um modelo de compreensão da realidade social, não apresentam uma solução capaz de estabelecer uma dialética entre reprodução e subversão, manutenção e transformação, garantia e eliminação, ampliação e liquidação.

A luta pelo reconhecimento, na perspectiva de Fraser (2008) tornou-se rapidamente a forma paradigmática do conflito político do Século XX. As demandas pelo reconhecimento das diferenças fazem com que as lutas dos grupos sociais se mobilizem sob as bandeiras da nacionalidade, eticidade, raça, gênero e opção sexual. Nestes conflitos a identidade de grupos sociais suplanta os interesses de classe como o principal meio de mobilização política. A dominação cultural suplanta a exploração como a injustiça fundamental e o reconhecimento cultural toma o lugar da redistribuição socioeconômica como medida de injustiça e objetivo de luta política. A luta pelo reconhecimento, no entanto, ocorre em um mundo de exacerbada desigualdade material o que significa que o desafio de desenvolver uma teoria crítica da 
sociedade em termos do processo de desenvolvimento socioeconômico requer o entendimento de que a justiça deve contemplar a articulação entre redistribuição econômica, reconhecimento social e representação política. Para Fraser, portanto, uma política de desenvolvimento que falhe no que diz respeito aos direitos humanos, por exemplo, é inaceitável mesmo que a mesma promova uma igualdade social. É exatamente neste ponto em que se estabelece o confronto entre a concepção tridimensional e a concepção centrada no monismo moral que reside a principal controvérsia entre, respectivamente, Fraser e Honneth (2003).

De fato, para Honneth (FRASER; HONNETH, 2003; HONNETH, 2009) o reconhecimento é uma categoria moral fundamental, enquanto a redistribuição é apenas uma subvariante do reconhecimento. Para Fraser (FRASER; HONNETH, 2003; FRASER, 1997) a redistribuição não pode se subordinar ao reconhecimento, pois ambas são categorias equivalentes, ou seja, uma não existe sem a outra. A perspectiva dualista de Fraser, portanto, é contraposta à concepção de monismo normativo de Honneth.

Os debates que se seguiram à análise de Fraser, levaram-na a retomar o tema do reconhecimento em outros estudos (FRASER, 2000; 2002a), abandonando a primeira versão em que reconhecimento é tratado de acordo com um modelo de identidade para abordá-lo como status, até porque Fraser introduzirá a questão da globalização em suas considerações (FRASER, 2002b; 2004). No modelo de status as dimensões se relacionam a diferentes aspectos da ordem social, de forma que o reconhecimento refere-se ao status da sociedade (grupos de status), enquanto a redistribuição refere-se à estrutura econômica (propriedade, mercado, trabalho, riqueza). Embora tenha introduzido a questão da representação no início dos debates (FRASER, 2002; 2004. FRASER; HONNETH, 2003), é, contudo, em uma análise mais extensa que Fraser (2008) revisa as suas teorias de reconhecimento e redistribuição e introduz definitivamente este terceiro elemento à sua reflexão da teoria crítica. A representação, para Fraser, corresponde à dimensão política.

Estabelecendo, agora, a relação da categoria do reconhecimento social com a dimensão sociocultural, que contempla também o nível ideológico, pode-se seguir uma linha argumentativa diversa daquela proposta por Honneth (2009). A dimensão sociocultural relaciona-se à superestrutura construída a partir das relações de produção no sentido da sua institucionalização, tendo como suporte um sistema de ideias capaz de conferir legitimidade às ações de um determinado sistema econômico. Isso acontece ao mesmo tempo no âmbito do Estado e de seus aparelhos como no das organizações em geral, ou seja, de todo aparato normativo de uma sociedade. O nível político, assim, recobre o jurídico. 
O nível político-ideológico está diretamente relacionado com as relações de dominação, que, em última instância, visam legitimar e garantir a permanência e reprodução das relações poder, condicionando o processo de desenvolvimento socioeconômico às determinações do sistema de capital. O nível político relaciona-se com o campo jurídico, pois o processo de trabalho e a apropriação dos resultados têm implicações jurídicas no que se refere às instâncias normativas e legais das relações de produção em que a estrutura legal do Estado moderno é uma exigência absoluta para a reprodução do modelo de desenvolvimento. No nível políticoideológico a estrutura da objetividade econômica precisa contar com uma estrutura de poder que lhe corresponda, já que demanda articulações entre ambas as estruturas, as quais se determinam duplamente, pois enquanto os elementos no nível econômico remetem às relações de propriedade, os elementos do nível político-ideológico remetem às relações de dominação, as quais devem garantir a permanência e a institucionalização daquelas, daí porque se tratam de relações de poder (FARIA, 2004, p. 98).

A ideologia opera no nível objetivo e subjetivo, consistindo no conjunto de teses explicitamente enunciadas e no conjunto de induções subjacentes (ENRIQUEZ, 1997). Desse modo, ela modela as representações conscientes que os atores sociais têm do sentido de sua ação, fazendo com que racionalizem parte de seus desejos inconscientes. Chauí (1982, p. 78; 1992) argumenta que a ideologia "não é um processo subjetivo consciente, mas um fenômeno objetivo e subjetivo involuntário produzido pelas condições objetivas da existência social dos indivíduos". Ademais, a ideologia é responsável por constituir os indivíduos concretos em sujeitos (ALTHUSSER, 1980, p. 96), sujeitos esses de um imaginário social instituído.

Além de sua função já exposta de interpretação e distorção da realidade, e de integração e redução dos conflitos, a ideologia também motiva, visto que compromete. Ela mobiliza os sujeitos de tal forma que se empenhem em realizá-la por meio de sua ação. Da mesma maneira, a ideologia é movida pelo desejo de demonstrar que o grupo que a professa tem razão de ser. Isso explica, em parte, o caráter reprodutor da ideologia, que, interiorizada, "produz consciências falantes, sujeitos que, encontrando no sentido recebido os meios de domínio simbólico, sentem sua vivência ideológica como a sua verdade; ela gera o acordo entre os sujeitos no terreno do simbólico, o acordo vivo entre as consciências que julgam conciliadas com a sua própria linguagem" (ANSART, 1978, p. 213). A ideologia não pode ser considerada, portanto, como se fosse mera abstração conceitual na análise dos processos democráticos de desenvolvimento socioeconômico, já que a ela cabe o condicionamento do pensamento aos interesses da reprodução do modelo de desenvolvimento tipicamente capitalista. 


\section{REPRESENTAÇÃo PARITÁRIA: DIMENSÃo JURÍDICO-POLÍtiCA DA ANÁLISE}

Como já abordado em outro estudo acerca da democratização da gestão (FARIA, 2009), é necessário, de pronto, estabelecer algumas condições do que se entende por representação paritária. Tal representação necessita valorizar a participação coletiva dos membros dos grupos ou classes sociais no processo decisório, enfatizando a partilha das responsabilidades em todas as instâncias ou fases do processo. A representação paritária tem como pressuposto básico o estabelecimento de relações de igualdade na medida em que rompe o processo de alienação, expande e estimula a difusão do conhecimento, além de destruir a estrutura social verticalmente hierarquizada, de forma que todos se tornem conscientes de sua responsabilidade para com o sucesso ou insucesso da ação.

A supressão da estrutura hierárquica preconiza o desenvolvimento de habilidades criativas nos sujeitos além de habilitá-los a tomar suas próprias decisões eliminando estruturas piramidais impostas. Tal objetivo não implica a instalação do caos, como argumentam os adeptos de necessidade de uma organização social burocrática para a viabilização da vida em sociedade. Pelo contrário, diz respeito muito mais a uma rede de relações baseada no desejo de cada sujeito individual ou coletivo fazer da organização um produto da discussão, das decisões e do controle do conjunto de seus membros.

Supressão da hierarquia, colaboração/cooperação entre setores de produção econômica e social, participação direta e efetiva, democratização das decisões, defesa de interesses sociais comuns e compartilhados, autocontrole do processo de trabalho pelos produtores diretos, autogestão da organização coletivista de trabalho, colaboração no planejamento e na execução dos projetos sociais, partilha das responsabilidades em todas as instâncias, preservação e valorização do trabalho coletivo, todas estas questões, entre outras, caracterizam a representação paritária dos sujeitos nas esferas de decisão.

A participação paritária dos sujeitos nas decisões coletivas deve considerar o grau de controle que os sujeitos possuem sobre quaisquer decisões em particular, as questões sobre as quais estas decisões são tomadas e o nível político no qual as questões objetos de tais decisões são definidas. Neste sentido, o acesso e o domínio das informações relevantes para que o processo de decisão paritária possa se efetivar é uma condição elementar para que a participação seja qualificada. Assim, é necessário que não apenas o acesso à informação seja 
disponibilizado, mas que esta informação esteja disponibilizada de modo a conceder condições mínimas para que os sujeitos possam se apropriar dela (VARGAS DE FARIA, 2003).

A participação paritária não deve desconsiderar a garantia de que uma democracia representativa, com dispositivos permanentes de controle, pode ser fundamental para a existência de uma autoadministração ou autogestão, ou seja, de que a democracia participativa constitua um recurso para a introdução da democracia direta onde ela for viável, o que quer dizer na base de todo o processo democrático de desenvolvimento socioeconômico. Pode-se, desta forma, desenvolver um sistema representativo de novo tipo, caracterizado pelo controle permanente dos representantes por parte dos representados e pela não separação entre o lugar da legislação (lugar normativo), o lugar coletivo e público da execução (lugar administrativooperativo, composto por agências, aparelhos, departamentos, repartições, unidades funcionais, organizações produtivas e sociais, etc.) e o lugar do julgamento dos conflitos (lugar judicial), criando um regime de assembleia.

A superação do estranhamento (alienação) é fundamental para a conquista de uma democracia participativa paritária que, embora não supere a representação, possa atuar com a finalidade de transformar os lugares administrativo-operativos, normativos e judiciais em instâncias efetivamente públicas e sociais, evitando que assuntos coletivos referentes aos processos democráticos de desenvolvimento socioeconômico se convertam em corpos estranhos à sociedade e que estes corpos estranhos sejam os determinantes da vida em sociedade.

Para Fraser (2008a, p. 39), “o significado mais geral de justiça é a paridade de participação. De acordo com esta interpretação democrática radical do princípio de igual valor moral, a justiça requer acordos sociais que permitam a todos participar como pares na vida social. Superar a injustiça significa desmantelar os obstáculos institucionalizados que impedem a alguns participar em igualdade com outros, como sócios com pleno direito na interação social".

Fraser argumenta que as pessoas podem ver-se impedidas de participar plenamente devido estruturas econômicas que lhes neguem os recursos necessários para interagir em condições de igualdade. Daí decorre uma injustiça distributiva ou uma má distribuição da riqueza. Neste caso, o problema encontra-se na estrutura de classes da sociedade. As pessoas também podem ver-se impedidas de interagir em condições de paridade por hierarquias institucionalizadas, de valor cultural, que lhes negam a posição adequada. As pessoas sofrem de uma desigualdade de status ou um reconhecimento falido. Neste caso, o problema é da ordem do status que corresponde à dimensão cultural. Embora a estrutura de classes e a ordem de 
status não se reflitam mutuamente com nitidez na sociedade capitalista contemporânea, as mesmas interagem. De qualquer forma, Fraser (2008a, p. 40) assegura que nem a primeira (redistribuição) e nem a segunda (reconhecimento) dimensão podem se reduzir a efeitos secundários, acessórios ou a epifenômenos uma da outra.

A terceira dimensão de justiça, para Fraser (2008a, p. 41), é a política. Fraser salienta, todavia, que distribuição e reconhecimento são também questões políticas, pois sofrem a rejeição e o peso do poder. Assim, o sentido de política que Fraser defende "remete à natureza da jurisdição do Estado e das regras de decisão com que se estrutura a confrontação”. O político "fornece o cenário em que se desenvolvem as lutas pela distribuição e pelo reconhecimento". A dimensão política, portanto, indica quem está incluído ou excluído do círculo dos que têm direito à redistribuição e ao reconhecimento, como se levanta e se arbitra as reivindicações e o que está na agenda das decisões no que se refere aos processos democráticos de desenvolvimento socioeconômico.

A dimensão política está centrada em questões de pertença e de procedimento, o que remete a discussão para o problema da representação e, portanto, das regras de decisão e das condutas que estruturam os processos públicos de confrontação. Se a paridade participativa nas decisões constitui-se em uma justiça política, a mesma defronta-se com obstáculos que se encontram na constituição da sociedade. Neste sentido é que Fraser (2008a, p. 44-47) distingue dois níveis de representação falida ou de injustiça política. A primeira injustiça política Fraser chama de "representação falida político-ordinária", que indica que as regras de decisão política negam injustamente a indivíduos que pertencem a uma comunidade a oportunidade de participar plenamente do processo sem distinção. A segunda injustiça política Fraser chama de “desdemarcação" "desmoldagem" ou "desenquadramento", que diz respeito ao aspecto político de delimitação (demarcação) de fronteiras. A injustiça ocorre quando as fronteiras se traçam de maneira que os sujeitos são injustamente excluídos em absoluto das possibilidades de participar nos confrontos de justiça que lhes competem. Trata-se da injusta delimitação da demarcação da referência política, do panorama social e politicamente criado.

A delimitação da demarcação, ao contrário de ter uma importância marginal, é uma das decisões políticas que tem muitas consequências, pois pode excluir aqueles não pertencem à comunidade ou grupo social do universo dos que têm direito de serem considerados integrantes destes coletivos, ou seja, a delimitação da demarcação define os politicamente incluídos e excluídos. Fraser (2008a, p. 51) chama a atenção para o fato de que uma política de representação deve ir além da tomada de posição contra as duas formas de injustiça: deve 
também aspirar "democratizar o processo de estabelecimento da demarcação", da "fixação de fronteiras". Uma política de representação para se considerar paritária deve definir quem são os sujeitos da justiça e qual a demarcação apropriada para manifestar explicitamente a divisão oficial do espaço político de forma a impedir que os desfavorecidos sejam obstruídos no enfrentamento das forças que os oprimem em suas reivindicações.

Por fim, Fraser (2008a, p. 124-129) indica que existem três princípios disponíveis para a avaliação das demarcações políticas, no que se refere a quem deve ser incluído na representação paritária:

\begin{abstract}
i. Princípio da condição de membro: propõe resolver as discussões sobre "quem" apelando para critérios de pertencimento político (cidadania, nacionalidade compartida, projetos comuns). Ao definir a delimitação da demarcação com base no pertencimento político, este princípio tem a vantagem de fundar-se em uma realidade institucional, a qual é também sua debilidade, pois facilita a ratificação da xenofobia excludente dos privilegiados e poderosos;

ii. Princípio do humanismo: propõe resolver disputas relativas a "quem" apelando a critérios que remetem ao ser humano, enquanto sujeitos que possuem em comum as características distintivas da humanidade (autonomia, racionalidade, linguagem, capacidade de aprender, sensibilidade, condições de distinção da boa e má moral). Ao delimitar a fixação das demarcações a partir do conceito de ser humano, este princípio é um freio crítico aos nacionalismos excludentes, mas sua elevada abstração é também uma debilidade, pois desconsidera as relações sociais e históricas e concede de forma indiscriminada posição social a todos a respeito de tudo;

iii. Princípio de todos os afetados: propõe resolver as disputas sobre "quem" apelando às relações sociais de interdependência, de forma que os sujeitos se submetam à justiça devido às co-imbricações em uma rede de relações causais. Este princípio tem o mérito de elaborar uma verificação crítica sobre a qualidade dos membros das coletividades tendo em vista as relações sociais. Ao conceber as relações de modo objetivo em termos de causalidade, entrega a definição de "quem" à ciência social dominante. Além disto, este princípio é vítima do "efeito borboleta" em que tudo e todos são afetados por tudo e por todos, tornando-se incapaz de identificar as relações sociais moralmente relevantes.
\end{abstract}

Para superar os problemas destes três princípios, Fraser propõe o que chama de princípio de todos os sujeitos.

"De acordo com este princípio, todos aqueles que estão sujeitos a uma determinada estrutura de governança estão em posição moral de ser sujeitos de justiça com relação a tal estrutura. Nesta perspectiva, o que converte o conjunto de concidadãos em sujeitos de justiça não é a cidadania compartilhada, como tampouco a posse comum de uma personalidade abstrata, nem o próprio fato da interdependência causal, mas sim a sua sujeição conjunta a uma estrutura de governança, que estabelece as regras básicas que regem a sua interação. Para qualquer estrutura de governança desse tipo, o 'princípio de todos os sujeitos' corresponde ao alcance de âmbito moral com o da sujeição a esta estrutura". (FRASER, 2008a, pp. 126-127)

O princípio proposto por Fraser oferece uma norma crítica para julgar as (in)justiças das demarcações. Desta maneira, uma questão está justamente demarcada se e somente se todos e cada um dos submetidos à(s) estrutura(s) de governança que regula(m) as áreas relevantes de 
interação social recebem igual consideração. Não é necessário que os sujeitos sejam membros formalmente credenciados da referida estrutura, mas que estejam sujeitos a ela. Dada a complexidade da organização social contemporânea é necessário distinguir os muitos quem (sujeitos) de acordo com distintas finalidades e objetivos, indicando quando e onde aplicar uma demarcação ou outra e, portanto, quem tem direito de participar paritariamente com quem em determinadas situações, ocasiões ou em determinados casos.

\section{A REALIZAÇÃO EMOCIONAL: A DIMENSÃO PSICOSSOCIAL DA ANÁLISE}

O nível psicossocial procura integrar os aspectos objetivos (econômicos, políticoideológicos) aos aspectos constitutivos do sujeito em sua vida social, ou seja, sua afetividade. Desta forma, a psicossociologia integra uma sociologia crítica a uma psicologia de base psicanalítica, ao relacionar o indivíduo/sujeito ao seu ambiente social, seja ele institucional, organizacional ou grupal (FARIA, 2004).

A realização emocional, que se apresenta como uma recompensa psíquica válida e validada pelo sujeito e pelo Outro, alude diretamente à noção de vínculo de reconhecimento. $\mathrm{O}$ vínculo de reconhecimento equivale à categoria do Amor a que se refere Honneth (2009), porém, diferentemente de sua concepção, não se trata de uma relação primária entre as formas de reconhecimento social. Ao contrário, trata-se, ela mesma, de uma categoria analítica tal como as demais (redistribuição, reconhecimento e representação). Assim, a relação entre identidade e vínculo de reconhecimento constitui a dialética entre o sujeito e o Outro, entre os grupos e as classes sociais. Em síntese, a dialética entre reconhecer-se e ser reconhecido.

Com este sentido, a concretização da realização emocional expressa a realidade conferida pelo Outro tendo em vista o resultado "bem sucedido" da ação. A realização emocional configura o lugar da alteridade, enquanto instância importante e fundamental para a afirmação do sujeito individual e coletivo, para a avaliação de suas possibilidades e limitações na prática social das relações com outros sujeitos e grupos sociais.

A realização emocional, enquanto sentimento e necessidade de reconhecimento no plano psíquico, como já mencionado, refere-se a quatro situações típicas, conforme ensina Zimerman (1999, p. 166-173):

$i$. Reconhecer a si mesmo: voltar permanentemente e se conhecer, ou seja, conhecer o que se encontra no sujeito e que está à espera de ser fecundado por realizações;

ii. Reconhecimento do outro enquanto sujeito diferente de si: romper o estado narcisista, considerando o outro não como um espelho de si, mas como sujeito autônomo, com concepções, condutas, atitudes e valores diferentes; 
iii. Ser reconhecido ao outro; expressar gratidão, transformando a onipotência, a prepotência e a onisciência em capacidade de pensar e aprender com as experiências, assumindo as relações de dependência e fragilidade;

$i v$. Ser reconhecido pelo outro como um sujeito individual ou coletivo; ao mesmo tempo, afirmar a própria existência autônoma, autorizar o estabelecimento de relações (de poder) e proteger-se contra as tentativas de quebra de vínculos originadas interna e externamente.

Esta última situação é a que diz respeito mais de perto a estas considerações. É vital para todo o sujeito individual ou coletivo (grupo social) ser reconhecido (necessidade de reconhecimento) para a afirmação de sua existência, identidade e autoestima. A falência desta necessidade, mesmo que seja referente aos níveis do pensamento, do conhecimento, ou do sentimento, e não da atitude explícita, significa a perda da condição de estabelecer relações com a realidade exterior. Para existir o sujeito necessita ser reconhecido, ou seja, necessita de uma realização emocional confirmada pelo Outro e não apenas de uma autorrealização egóica. Ser reconhecido, sentir-se realizado emocionalmente, significa a valorização de si (sujeito ou grupo social) pelo Outro (sujeito ou grupo social), que se constitui na garantia real da existência (do sujeito ou grupo social) como uma individualidade ou unidade. Como sugere Lacan (1966), o sujeito se reconhece no Outro e por meio do Outro. Isto traduz a admissão de que na vida social as relações, mesmo as mais primárias, prevalecem sobre os sujeitos.

O vínculo do reconhecimento, a recompensa afetiva ou a realização emocional, do ponto de vista das relações que se desenvolvem no plano dos processos democráticos de desenvolvimento socioeconômico, ao mesmo tempo em que são necessárias e fundamentais para a existência dos sujeitos enquanto sujeitos autônomos desenvolvem dialeticamente a angústia da separação. De fato, a angústia da separação representa o medo da quebra do vínculo nas condições em que o sujeito (individual ou coletivo) o estabeleceu. Sendo assim, à pergunta recorrentemente expressa sobre "por que o sujeito não reage às condições de vida que o fazem se indignar?" corresponde a resposta de que sua omissão se dá em grande medida pela angústia da separação, pois esta contém as incertezas, os anseios, as inquietudes e sofrimentos. Em outros termos, na luta dialética pulsional, o sujeito é seduzido pela conservação (pulsão de morte, Thanatos) e não pela transformação, pela mudança (pulsão de vida, Eros).

Tendo o sujeito estabelecido vínculos afetivos, econômicos, ideológicos e socioculturais com a sociedade em que vive, também estabelece uma relação de pertença que não consegue ser rompida devido ao medo da separação, e de suas consequências tais como construídas pelo imaginário da dependência. $\mathrm{O}$ sentimento de abandono que acompanha o rompimento com o meio social ou com o grupo social afeta a estrutura narcísica essencial do sujeito, de maneira que não ser reconhecido como membro deste coletivo, não realizar-se emocionalmente com a realização coletiva, não falar e não ser falado, equivale a não existir. 
Por isso é que a trama social é percebida pelos indivíduos como um conjunto de condicionantes estruturais que regem a vida em sociedade, estritamente ordenada por regras e normas mediadas pela linguagem. Segundo Enriquez (1974, p.54), na medida em que cada um é levado a procurar seu lugar na estrutura social, "tudo ocorre como se a vida fosse estritamente formalizada e pudesse ser apreendida e controlada". Neste sentido, o indivíduo não é criador de suas relações, ou seja, a realidade lhe é dada como algo pronto, sem capacidade de transformação ou sua apropriação real.

A distância existente entre o objeto de conhecimento e o objeto real deve ser analisada em sua essência e não somente na aparência do fenômeno. Nestas condições pode-se compreender melhor como esta concepção ingênua do visível imediato é uma concepção construída e, como toda construção, ela só deixa ver aquilo que ela quer, o que significa "que não há nada atrás da cena do manifesto; que o que é vivido não remete a nada, senão àquilo que é expresso; e que cada um é totalmente definido pelo que diz e pelo que faz" (ENRIQUEZ, 1974, p.56-57).

Nesta perspectiva de absorver a realidade num âmbito mais complexo, é preciso buscar o que há nos bastidores desse real, o não-dito, a outra cena e cabe a psicossociologia tal análise mais intensa. Em sua busca constante de seu lugar na estrutura social, o indivíduo depara-se com o jogo do desejo, na luta pelo seu reconhecimento, já que a consciência de si provém de sua afirmação e reconhecimento pelo outro. A psicossociologia teria por objetivo, nas palavras do próprio Enriquez, "elucidar a (ou as) significação(ões), talvez mesmo os sentidos divergentes (ou não-sentidos) que organizam o funcionamento da outra cena" (ENRIQUEZ, 1997, p.29).

Esta abordagem conduz à consideração de outros elementos, distintos daqueles tradicionalmente tratados pelas teorias do desenvolvimento socioeconômico, para se compreender as relações de poder na sociedade. Os processos grupais, a construção de um imaginário social, de um sistema de valores comum (representações) e seus respectivos mecanismos de identificação e idealização são elementos centrais.

A identificação deve ser entendida enquanto um processo psíquico através do qual um sujeito assimila características do outro, adotando-o como modelo e transformando-se. A personalidade se constitui por sucessivas identificações (LAPLANCHE \& PONTALIS, 1986). Esse processo representa um estabelecimento de um vínculo (investimento) afetivo do indivíduo com o Outro. Já a idealização, constitui o mecanismo que permite a toda a sociedade instaurar-se e manter-se, e a todos os indivíduos viverem como seus membros, pois a 
possibilidade de constituição de qualquer pacto social pressupõe algum nível de idealização sobre o coletivo (ENRIQUEZ et al., 1994).

Para construção de um projeto social comum é necessário que as representações sobre a organização social sejam não apenas intelectualmente pensadas, mas afetivamente sentidas. "não se trata unicamente de querer coletivamente; trata-se de sentir coletivamente" (ENRIQUEZ, 1994, p. 57). Esse sentimento, fonte do comportamento grupal, só pode emergir se ligado a um sistema de idealização, fruto de processos conscientes e inconscientes. $\mathrm{O}$ processo de idealização é o que dá "consistência, vigor e aura excepcional" tanto ao projeto quanto aos indivíduos, possibilitando-os de partilhar da mesma ilusão (ENRIQUEZ et al., 1994, p. 57).

Partindo do pressuposto de que toda sociedade dispõe de uma estrutura de valores e de normas que condicionam seus membros a certa forma de apreensão do mundo e de orientação de suas condutas, as formas organizadas do coletivo devem ser entendidas enquanto uma microssociedade por excelência e consequentemente atravessada pelos mesmos problemas que caracterizam o vínculo social (ENRIQUEZ, 2000). Toda vida em sociedade é geradora de angústias. Do mesmo modo, a organização coletiva igualmente enfrenta várias angústias. $\mathrm{O}$ indivíduo se liga às organizações sociais (associação de moradores, sindicatos, partidos, etc.) por vínculos não apenas sociais e materiais, mas, sobretudo afetivos e imaginários, e essas organizações, embora não criem uma estrutura psíquica, utilizam-se dela (FREITAS, 1999).

Neste sentido, a tão esperada adesão dos indivíduos aos projetos de organização social pode ser o resultado de dois tipos de processos que, na realidade se apresentam combinados e que são decorrências da produção de um sistema imaginário pela organização. No primeiro caso, tal organização se apresenta como a instância central capaz de responder aos desejos narcísicos de reconhecimento, ao fantasma de onipotência dos indivíduos, assegurando proteção contra quebra de suas identidades. Desse modo, tende a substituir o imaginário do indivíduo pelo seu próprio, apresentando-se como superpoderosa e nutriz, aprisionando-o em um "imaginário enganoso" (ENRIQUEZ, 1997), que o impossibilita de produção autônoma e criativa.

Outra possibilidade é essa organização engendrar o que Enriquez (1997) denomina de “imaginário motor”, favorecendo a criatividade e sendo capaz de conviver com mudanças e rupturas. Um imaginário que comporta a espontaneidade, a experimentação e o pensamento questionador. Por ser este um imaginário que abre espaço para o questionamento da própria 
organização e de suas regras, ele tende a ser muito menos desenvolvido que o primeiro (FREITAS, 1999).

Desta forma, observa-se que no nível psicossocial encontra-se a explicação para o movimento de vinculação entre os sujeitos concretos, que é essencial para o reconhecimento dos interesses em comum em processos democráticos de desenvolvimento socioeconômico. Por apresentar uma dinâmica dialética, em que sempre polos antagônicos (prazer e angústia, alienação e reconhecimento, repetição e superação) estão em jogo, entende-se que esse nível de análise representa uma peça importante para a compreensão das relações de poder nas organizações sociais. Em resumo:

Quadro 1 - Aspirações do Sujeito Coletivo na Vida em Sociedade

\begin{tabular}{|c|c|l|}
\hline $\begin{array}{c}\text { O que o Sujeito } \\
\text { Coletivo aspira ser }\end{array}$ & $\begin{array}{c}\text { Categorias de Análise } \\
\text { correspondentes }\end{array}$ & Elementos constitutivos das Categorias de Análise \\
\hline $\begin{array}{c}\text { Socialmente } \\
\text { reconhecido }\end{array}$ & $\begin{array}{c}\text { Reconhecimento } \\
\text { Social }\end{array}$ & $\begin{array}{l}\text { Objetivação Normativa } \\
\text { Inserção nos Espaços Coletivos de Poder (pertença) } \\
\text { Definição de um Projeto Social Comum }\end{array}$ \\
\hline $\begin{array}{c}\text { Economicamente } \\
\text { recompensado }\end{array}$ & $\begin{array}{l}\text { Redistribuição da } \\
\text { Riqueza Material }\end{array}$ & $\begin{array}{l}\text { Distribuição Igualitária da Riqueza } \\
\text { Acesso aos Bens Públicos e à Infraestrutura urbana e social } \\
\text { Retribuição Justa pelo Trabalho Realizado } \\
\text { Acesso aos Resultados da Produção Social }\end{array}$ \\
\hline $\begin{array}{c}\text { Politicamente } \\
\text { representado }\end{array}$ & $\begin{array}{c}\text { Representação } \\
\text { Política Paritária }\end{array}$ & $\begin{array}{l}\text { Acesso às Esferas Públicas de Decisão } \\
\text { Práticas Políticas Coletivas } \\
\text { Inserção na Gramática do Conceito de Justiça }\end{array}$ \\
\hline $\begin{array}{c}\text { Emocionalmente } \\
\text { realizado }\end{array}$ & Realização & $\begin{array}{l}\text { Sublimação Coletiva }{ }^{2} \\
\text { Desejo do Reconhecimento do Desejo } \\
\text { Afirmação da Identidade } \\
\text { Recompensa Emocionalmente Avaliada }\end{array}$ \\
\hline
\end{tabular}

Fonte: Elaborado pelo autor.

\section{CONSIDERAÇÕES FINAIS}

Partindo dos conceitos de interdisciplinaridade pode-se perceber que os processos de desenvolvimento socioeconômico têm se restringido a, no máximo, uma visão bidisciplinar. Mais do que isso, são processos não democráticos que se subordinam aos interesses do sistema de capital. Para pensar estes processos democráticos de desenvolvimento socioeconômico de forma interdisciplinar, é preciso considerá-los a partir de critérios de justiça social.

\footnotetext{
${ }^{2}$ No sentido da modificação de um impulso ou energia coletiva original (já instituído), de forma a manifestar outra ação ou atitude que venha a ser aceita e valorizada (legitimada) pela sociedade em razão de que sua finalidade é considerada superior do ponto de vista valorativo.
} 
O problema que se coloca é, portanto, organizar a compreensão do campo empírico dos empreendimentos coletivos que possam desencadear processos democráticos de desenvolvimento socioeconômico de forma interdisciplinar a partir das categorias de análise em sua quadridimensionalidade. Considera-se que as dimensões aqui propostas são abstrações do real condensadas em categorias analíticas, ou seja, é um recurso de análise inspirada na realidade enquanto síntese de múltiplas contradições. Assim, as considerações empreendidas pretendem orientar e organizar a apreensão da realidade como realidade pensada.

É condição primordial para o estabelecimento de uma gestão democrática dos processos democráticos de desenvolvimento socioeconômico que haja um permanente questionamento acerca da forma com que são organizadas as condições de existência, de maneira a se garantir: (i) a justiça nos processos de reconhecimento social dos grupos autônomos e emancipados; (ii) a distribuição igualitária da riqueza coletivamente produzida; (iii) a participação paritária nas esferas públicas de decisão; (iv) a realização emocional pelos resultados da práxis política dos sujeitos.

Compreender as condições objetivas e subjetivas pelas quais os sujeitos coletivos produzem suas condições de vida em sociedade revela muito acerca das probabilidades de consolidação de processos democráticos de desenvolvimento socioeconômico.

\section{REFERÊNCIAS}

ALTHUSSER, L. Ideologia e Aparelhos Ideológicos de Estado. Porto: Presença, 1980.

ANSART, P. Ideologias, Conflitos e Poder. Rio de Janeiro: Zahar, 1978.

BARDIN, L. Análise de conteúdo. Lisboa: Edições 70, 1977.

BERNSTEIN, P. Worker ownership and community development. The Corporate Examiner. Mar. 1981.

BERNSTEIN, P. Workplace democratization: its international dynamics. Kent: Kent University Press, 1976.

BOBbio, N.; MATTEuCCI, N. e PASQUinO, G. Dicionário de Política. Brasília: Universidade de Brasília, 1986.

CASTEL, R. A metamorfose da questão social. Petrópolis: Vozes, 1998.

CHAUÍ, M. O que é ideologia. São Paulo: Brasiliense, 1982.

CHAUÍ, M. Público, privado e despotismo. In: NOVAES, A. Ética, Rio de Janeiro: Companhia das Letras, 1992. p.345-390.

CRUZ, A. O Mar e a Terra da Economia Solidária. Leituras Cotidianas. n.181, jun. 2005. 
DRU, J. O Estado, o plano e a república dos conselhos. Porto: Paisagem, 1975.

ENRIQUEZ, E. Imaginário social, recalcamento e repressão nas organizações. Revista Tempo Brasileiro, Rio de Janeiro, vol. 36/37, pp. 54-97, jan./jun. 1974.

ENRIQUEZ, E. Organização em análise. Petrópolis: Vozes, 1997.

ENRIQUEZ, E. Vida psíquica e organização. In: MOTTA e FREITAS (2000).

ENRIQUEZ, E.; DUBOST, J.; LEVY, A.; NICOLAÏ, A. Psicossociologia: análise social e intervenção. Petrópolis: Vozes, 1994.

FARIA, J. H. de. Economia Política do Poder. Curitiba: Juruá, 2004. 3 Volumes.

FARIA, J. H. de (Org.). Análise crítica das teorias e práticas organizacionais. São Paulo: Atlas, 2007.

FARIA, J. H. de. Gestão Participativa: relações de poder e de trabalho nas unidades produtivas. São Paulo: Atlas, 2009.

FRASER, N. A Justiça Social na Globalização: redistribuição, reconhecimento e participação. Revista Crítica de Ciências Sociais. (63):7-20, out., 2002 b.

FRASER, N. Adding Insult to Injury: London: Verso, 2008b.

FRASER, N. Escalas de Justicia. Barcelona: Herder Editorial, 2008a.

FRASER, N. Justice Interruptus: critical reflections on the "post socialist" condition. New York: Routledge, 1997.

FRASER, N. Recognition, Redistribution and representation in Capitalist Global Society: an interview. Acta Sociologica, 47(4):274-382, dec., 2004.

FRASER, N. Redistribuição ou Reconhecimento? Classe e status na sociedade contemporânea. Rui de Janeiro: Interseções, UERJ, 4(1):7-32, 2002a.

FRASER, N. Rethinking Recognition. New York: New Left Review (3):107-120, 2000.

FRASER, N.; HONNETH, A. Redistribution or Recognition? A political-philosophical exchange. London: Verso, 2003.

FREITAS, M. E. de. Cultura Organizacional: Identidade, sedução e carisma. São Paulo: Editora da FGV, 1999.

GREENBERG, E. S. Workplace Democracy: the political effects of participation. Ithaca: Cornell University Press, 1986.

GUILLERM, A. \& BOURDET, Y. Autogestão: uma mudança radical. Rio de Janeiro: Zahar, 1976.

HEGEL, G. F. Fenomenologia do Espírito. Petrópolis: Vozes, 2008.

HONNETH, A. Disrespect: the normative foundations of Critical Theory. Malden: Polity Press, 2008a.

HONNETH, A. La Société du Mépris. Paris: La Découvert, 2006

HONNETH, A. Luta por Reconhecimento: a gramática social dos conflitos sociais. São Paulo: Editora 34, 2009. 
HONNETH, A. Reificación: un studio en la teoria del reconocimiento. Buenos Aires: Katz, 2007b.

HONNETH, A. Sofrimento de Indeterminação. São Paulo: Singular/Esfera Pública, 2007 a.

HONnETH, A. The Critique of Power: reflective stages in a critical social theory. Cambridge: MIT Press, 1991.

HONNETH, A. Trabalho e Reconhecimento: tentativa de uma redefinição. Civitas. Porto Alegre (8):1, pp. 46-67, jan.-abr. 2008 b.

KOJEVE, Al. Introdução à leitura de Hegel. Rio de Janeiro: Contraponto/EDUERJ, 2002.

KOSIK, K. Dialética do concreto. $7^{\text {a }}$. Ed. Rio de Janeiro: Paz e Terra, 2000.

LACAN, J. Le Stade du Miroir comme formateur de la fonction du JE. In: Écrits. Paris: Seuil, 1966.

LAPlAnCHE, J. B.; PONTAliS, J. Vocabulário da Psicanálise. São Paulo: Martins Fontes, 1986.

LUXEMBURGO, R. Reforma Social ou Revolução? São Paulo: Global, 1986.

MARX, K. Contribuição à Crítica da Economia Política. São Paulo, Martins Fontes, 1977.

MARX, K. El Capital: crítica de la economia politica. Buenos Aires: Biblioteca Nueva, 1946.

MARX, K. ENGELS, F. A Ideologia Alemã. São Paulo: Boitempo, 2007.

MATTOS, P. A Sociologia Política do Reconhecimento: as contribuições de Charles Taylor, Axel Honneth e Nancy Fraser. São Paulo: Annablume, 2006.

MÉSZÁROS, I. Para além do capital: rumo a uma teoria da transição. São Paulo: Boitempo, 2002.

MONTUCLARD, M. Autogestão e dialética. Porto: Paisagem, 1975.

NOVAES, A. (Org.). Ética. São Paulo: Companhia das Letras, 1992.

PAGÈS, M. A Vida Afetiva dos Grupos. Petrópolis: Vozes, 1982.

PAGÈS, M.; BONETTI, M.; GAULEJAC, V. de; DESCENDRE, D. O poder das organizações: a dominação das multinacionais sobre os indivíduos. São Paulo: Atlas, 1993.

SILVA, J. P. da. Trabalho, Cidadania e Reconhecimento. São Paulo: Annablume, 2008.

SouZA, J.; MATTOS, P. (Orgs.). Teoria Crítica no Século XXI. São Paulo: Annablume, 2007.

TAYLOR, C. Argumentos Filosóficos. São Paulo: Loyola, 2000.

TAYLOR, C. As Fontes do Self: a construção da identidade moderna. 2a . Ed. São Paulo: Loyola, 2005.

TAYLOR, C. Imaginários Sociais Modernos. Lisboa: Texto \& Grafia, 2010b.

TAYLOR, C. Uma Era Secular. São Leopoldo, Editora Unisinos, 2010 a. 
TEIXEIRA, L. R. A Ideologia Política na Economia Solidária: uma análise de empreendimentos solidários em Salvador. São Paulo: Hucitec, 2010.

VARGAS DE FARIA, J. R. Organizações Coletivistas de Trabalho: autogestão nas unidades produtivas. Curitiba: UFPR, 2003. Dissertação de Mestrado em Administração.

YOUNG, I. M. Justice and the Politics of Difference. Princeton: Princeton University Press, 1990.

ZIMERMAN, David E. Fundamentos Psicanalíticos: teoria, técnica e clínica. Porto Alegre: Artmed, 1999. 